\title{
Miranda
}

Revue pluridisciplinaire du monde anglophone /

Multidisciplinary peer-reviewed journal on the English-

speaking world

\section{7| 2012}

Ceramics / Submorphemics

\section{"Toujours la porcelaine": George Meredith and the Willow Pattern}

\section{Catherine Lanone}

URL: http://journals.openedition.org/miranda/4450

DOI: $10.4000 /$ miranda.4450

ISSN: 2108-6559

\section{Publisher}

Université Toulouse - Jean Jaurès

\section{Electronic reference}

Catherine Lanone, "'Toujours la porcelaine": George Meredith and the Willow Pattern", Miranda [Online], 7 | 2012, Online since 09 December 2012, connection on 16 February 2021. URL: http:// journals.openedition.org/miranda/4450 ; DOI: https://doi.org/10.4000/miranda.4450

This text was automatically generated on 16 February 2021.

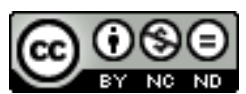

Miranda is licensed under a Creative Commons Attribution-NonCommercial-NoDerivatives 4.0 International License. 


\title{
"Toujours la porcelaine": George Meredith and the Willow Pattern
}

\author{
Catherine Lanone
}

1 According to Roland Barthes, "[m]yth is not defined by the object of its message, but by the way in which it utters this message: there are formal limits to myth, there are no 'substantial' ones. Can everything, then, be a myth?" (Barthes 109) Barthes concludes his analysis of iconic objects, which range from soap-powders to the national flag, cars and Garbo's face, by claiming that every object may be turned into an icon, a myth, provided it offers an image which may be appropriated by society to convey a specific message. Barthes's semiological analysis is apposite to the nineteenth-century fascination with blue china, and to the motif of the "willow pattern" in particular. Shifting from upper-class taste to mass production, the popular motif of the "willow pattern" emblematizes the desire for domestic beauty, but may also be read as an icon or a myth, a frozen image which seems innocent enough but which implies a kind of "surreptitious faking", something which is stolen and replaced, frozen into an apparently eternal reference (Barthes 125). Intertextual allusions to the "willow pattern" explore this shift from use value to symbolic exchange value, as china becomes a sign of distinction, taste and social status, but also of mass production, a problematic icon which reveals the fragile, deceptive nature of modernity.

2 Like painting, porcelain is a visual art, and texts seek to represent it through ekphrasis. A poem by the Victorian Scottish poet Andrew Lang encapsulates the dreamy series of images that weave the narrative of the willow pattern: insisting on temporality through the use of a refrain ("In the reign of the Emperor Hwang"), Lang begins with the pleasure of china as matter, substance (note the alliteration, "gloat on the glaze"), then shifts to the archetypal colours and the satisfactory roundness of the pot, which has stood the trial of time, before offering the elements of the tale, the tree, the lovers, the bird:

There's a joy without canker or cark

There's a pleasure eternally new

'Tis to gloat on the glaze and the mark

of china that's ancient and blue; 


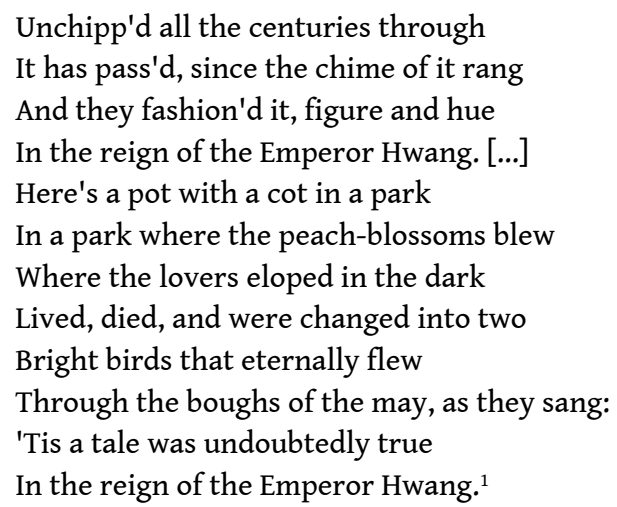

Lang picks up the elements of the tale ${ }^{2}$, which was believed to have been inspired by ancient Chinese pottery and with which the Victorians would have been extremely familiar (there was even a nursery rhyme summing up the tale of the willow pattern lovers; see Chang 109). Lang's self-contained world of wonder recalls Keats's Ode on a Grecian Urn, replacing the "Cold Pastoral" with the familiar blue china romance. The urn has turned into a simple pot, yet no less pleasure is derived from Chinese romance as from Greek perfection, as is suggested by the rhyme which entwines the colour blue and the flight of true love ("blue" /"hue" / "blew" / "two" /"flew" / "true"). The word "true" echoes at the end of the line, recalling Keats's equation between truth and beauty which concludes his Ode on a Grecian Urn. Here too, as in Endymion, "a thing of beauty is a joy forever": the "china that's ancient and blue" brings "pleasure eternally new". Whereas the lovers were frozen in eternal pursuit on Keats's urn, they are turned into birds, and united through metamorphosis.

Though Lang is a lesser poet than Keats, there is something significant in his attempt to place art in a different context, a different frame of cultural reference, not the smooth sculpture of Greece, but the colours of China. The Keatsian echoes may be seen as fragments of textual pottery, or to use Harold Bloom's concept, tessera ${ }^{3}$. For Lang, the "Cold Pastoral" is not enough, one must add to beauty, perfect craftsmanship and the legacy of time, a happy ending; the metamorphosis delighted Lang, who was a great fan of fairy tales and spoke of his ecstasy before the white and blue china motif. The lovers are not defeated but united, transfigured by the mutation into birds forever flying far above human strife. The sentimental rewriting of Keats's myth turns pottery into the modern metonymy of perfect art. A cornucopia of images, the willow pattern became popular not simply among the middle classes but also among the lower classes (Chang 109), as a kind of picture book from which a tale could always be told. Thus the willow pattern was perceived, first and foremost, as a romantic motif and a narrative object, as much as a useful object.

It is no surprise that by 1880 a white-and-blue porcelain vase should replace the Grecian urn as an emblem of artistic refinement and perfection. This may be construed as a reflection of art and contemporary pictorial displays of beautiful china. Not only was Chinese porcelain an important feature in elegant Victorian interiors, but it became a recurrent motif in portraits of upper-class ladies, from realist to PreRaphaelite painters (see Rossetti's 1867 Monna Rosa, depicting a woman arranging flowers in a white and blue china vase). In Whistler's 1864 Purple and Rose: The Lange Leizen of the Six Marks ${ }^{4}$, attention is distracted from the woman's face by the china pots and plate which lead the spectator's gaze around her rather than towards her, while her own attention is focused on the blue and white vase which she is holding on her 
lap. John Singer Sargent displays a similar taste for white and blue Oriental china. In The Daughters of Edward Darley Boit (1882), Sargent uses two pillar-like vases to enhance the porcelain beauty of the little girls. The vases were actually much smaller than the girls (they may be seen on display in the Museum of Fine Arts, in Boston), so that Sargent's painting magnifies the vases; it has an eerie Alice-in-Wonderland quality as it seems to blur the boundary between the animate and the inanimate, between the girls and the vases (vases, which, like purses, were often used to signify female identity and the female body in Victorian literature). The girls and the porcelain become enigmatic, in a visually perfect, almost abstract, but also disturbing relation between vase and girl.

But the willow pattern was a more commonplace piece of pottery than such elegant emblems. In an 1852 issue of Household Words, Charles Dickens gives a surprising view of the technique of pattern printing: a blue willow pattern plate speaks for itself, boasts of its own design and details its own creation, complete with an "astounding blue willow tree", and "that amusing blue landscape, which has, in deference to our revered ancestors of the Cerulean Empire, and in defiance of every known law of perspective, adorned millions of our family since the days of the platters", thus insisting on mass production as much as aesthetic perfection. A tribute to modern technology, the printed plate becomes the equivalent of Dickens's printed article (entitled "A Plated Article"). Elizabeth Hope Chang points out that personifying objects was a common device after the 1851 Great Exhibition, and suggests that the willow pattern articulates the way British writers explore their relationship with commodities and the colonial discourse of the Empire: "Thus, repeated dismissals of the pattern as a fleeting fashion belie the snowballing power of its cultural presence: the willow pattern came to be this national touchstone because it was always present as a point of reference, whether in imagination or in point of fact" (Chang 89).

But if it was a popular object rather than an emblem of highbrow art, it might be surprising to see the willow pattern feature significantly in literature (whereas it remained a background element in paintings like William Henry Hunt's 1842 Hearing Lessons: a Cottage Interior, where it was taken for granted as part of ordinary life, and not foregrounded as an emblem of aestheticism ${ }^{5}$. Though a poetic tribute may not be deemed so very unusual, it is certainly unexpected to find a central pun on the motif of the willow pattern in a full-scale novel, as it is in George Meredith's The Egoist (1879).

8 The Egoist might be compared with Sargent's painting, The Daughters of Edward Darley Boit, in so far as it magnifies porcelain, but it also turns it into an almost abstract motif, a metaphor of gendered conflict and female identity. In the novel, porcelain is a gift, a thing of beauty associated with femininity, in keeping with the Victorian ethos of ethereal idealization and angelic constraint. But Meredith's protagonist Clara, a girl who loves to run, refuses to be cast into a china mould. Ultimately, it is the male protagonist (whose name recalls the motif) who is turned into an outmoded product, a brittle model of upper-class petrified prejudice.

George Meredith was a famous writer in his day, one of these formidable bearded eminent Victorians whom Virginia Woolf and the Bloomsbury Group were to be so wary of. His style too was formidable, full of zest and humour, but also of deliberate intricacies and mannerisms, which soon came under attack. Forster, who pays tribute to Meredith in A Room with a View, notes in his 1927 Aspects of the Novel that he no longer seems the great name he used to be, an argument which Woolf picks up by paying lip service to Meredith as a master of style, an example of supreme English prose, only to 
say that that was twenty years ago, and to conclude that he is "meretricious and false" (Woolf 539): "Meredith has not worn well" (Woolf 533). The idiosyncratic complexity of this English Henry James has never returned to its former fame. Rather than for his best novels, The Egoist, The Ordeal of Richard Feverell and Diana of the Crossways, or his sequence of sonnets (dealing with divorce and aptly entitled Modern Love), Meredith is perhaps most remembered today for having been immortalized by the Pre-Raphaelite painter Wallis as the young poet Chatterton, and for having become a character in Peter Ackroyd's post-modern novel Chatterton (Wallis ran away with Meredith's wife, who died a couple of years later, Meredith having refused ever to see her again).

There is guilt and atonement in Modern Love, and perhaps in The Egoist too, a long Victorian three-decker which goes against the rules by featuring a protagonist who is not a sympathetic character, who remains thoroughly blind and unpleasant to the end. With bitter, relentless accuracy, Meredith dissects the selfishness of a male specimen of the English upper classes, who treats women as objects or mirrors destined to enlarge his narcissistic self. A comedy of manners, Meredith's Egoist owes a debt to the English tradition, especially Jane Austen, so that the porcelain motif may be taken as a symptom of Meredith's desire to play with, but also to modify the comedic traditionin other words, as tessera. As we begin The Egoist, we might believe that the plot will unravel according to familiar lines; Clara, who is engaged to the protagonist, Sir Willoughby Patterne, will free herself from his selfish domination, and become aware that she truly loves his penniless secretary, Vernon Whitford; Willoughby will marry his long suffering, devoted admirer, Laetitia Dale-in other terms, an updated version of Pride and Prejudice. And so it goes on, with a twist: Clara will become fond of Vernon, whereas Willoughby is exposed, jilted, so that he desperately wants to marry Laetitia, to clothe himself against the world's scorn; but she no longer loves him, and marries him for money. The end is as grim and bitterly ironic as the whole novel, and Willoughby Patterne stands his same old self, wounded but unredeemed.

Within the plot, porcelain does not simply function as a token of beauty associated with upper-class life, a sign of social as well as aesthetic distinction. As onomastics would have it, Willoughby Patterne is the very pattern of an English gentleman, the handsome owner of a country house with a lovely park: Mrs Mountstuart Jenkinson's sentence describes him, like a leitmotif or a single stroke of a brush: "you see he has a leg" (12). Clara, his beautiful future bride, is repeatedly associated with porcelain, as befits Victorian representations of femininity. Instinctively, Lady Busshe and Colonel De Craye offer Clara porcelain as a wedding present, a fact which is signalled by the characters, in fashionable French: “Toujours la porcelaine!" (285) The admirative Mrs Mountstuart Jenkinson, who is utterly fond of epigrams, calls Clara a "dainty rogue in porcelain" (36). The formula, however, is highly ambiguous; Clara may be dashing enough to be pleasantly compared to a rogue, but rogue is also a technical term meaning flawed china; the epigram is emblematic of the girl's beauty, but also signals a fundamental flaw in the relationship, as if Clara's vows were bound to be broken. The wedding gifts are equally ambiguous: De Craye's vase is broken when his carriage is overturned, a hint of broken vows to come, while Lady Busshe has already offered once before the lovely service she presents to Willoughby and Clara, for a first failed attempt at marriage.

12 The novel thus steers away from ekphrasis, refusing to describe the willow pattern which is only evoked through Willoughby's name. However, the story remains 
programmatic, a joke which Victorian readers would have easily grasped: Willoughby, the would-be lover, is cast as the mandarin seeking to prevent a shameful elopement. But Clara wanders off in the park and chances upon Vernon (a secretary, just like the lover in the so-called Chinese legend) as he lies beneath a double-blossom wild cherrytree. Clara sees "the load of virginal blossom, whiter that the clouds", it "[showers] and [droops] and [clusters] so thick as to claim colour", "a flush of white", an oxymoron which connotes her sensuous awakening as she meets Vernon as a man, rather than a background figure in her life: "She looked down. Vernon was dreamily looking up." (95) The scene mingles Endymion with the cherry blossom of Japanese etchings, and fits in with the tree motif in the willow pattern plate. The lovers end up, not quite turned into birds, but the next best thing in terms of altitude, in the Alps. Before then, throughout the novel, little happens except Clara's excruciating indecision and Willoughby's suicidal selfishness. Meredith paints the birth of unconscious desire in Clara through little Freudian slips before the word, as she catches herself uttering Vernon's name by mistake - a study in mental opacity and transparency which may suggest Meredith's attempt to transpose the fine quality of china into writing itself. Willoughby demands idolatry and wishes his bride to be a mirror, a chalice. Almost all his sentences revolve around the "lamentable letter I" (92), and he constantly claims Clara as his, "mine", so that she begins to perceive herself as hopelessly trapped. Meredith expands Donne's pun on love's imposture: "Love's Alchemy" opens with a famous image of excavation, "Some that have deeper digg'd love's mine than I". Similarly in The Egoist, we shift through syllepsis from mine to a mine, a dreary one at that: "To be fixed at the mouth of a mine and to have to descend in it daily, and not to discover great opulence below; on the contrary, to be chilled in subterranean sunlessness, without any substantial quality that she could grasp, only the mystery of inefficient tallow-light in those caverns of the complacent talking man" (48). Significantly, Clara sees herself as "a victim decked for the sacrifice- the garlanded heifer you see on Greek vases, in that array of jewellery" (83), a direct allusion to Keats's Grecian urn.

13 The novel is a curious object, with its often unpalatable contorted prose, yet with its feminist claim for understanding and subtlety, which uses the willow pattern as a graphic call for freedom. As Serge Cottereau has shown ${ }^{6}$, there is a striking use of ventriloquism as the narrative voice sarcastically mimics Willoughby's thoughts. Thus, by choosing the willow pattern as his emblematic scenario, Meredith calls for a feminist revision of gendered roles. Interestingly enough, it is the very pattern of an English gentleman which is flawed, shattering conventional expectations. The porcelain motif becomes an instance of social deconstruction, all the more so as the choice of the willow pattern itself points to imposture and simulacrum. For one thing, the willow pattern cannot be described, since it cannot be on the vases offered to Clara because, by that time, the willow pattern was no longer an expensive, delicately crafted piece of porcelain, but a commodity, a terribly popular commodity.

14 Above all, the very pattern was an imposture too. Meredith plays on the way in which blue and white porcelain, including the willow pattern, was marketed as a reflection of the art and craft of ancient China, supposedly simply revived in modern Victorian Britain. In fact, the pattern was created in the 1780 's by Josiah Spode, by putting together various Chinese motifs, the willow tree, the bridge, the boat, the characters in the distance, the blue geometric frame. And it was a definitely English, composite imitation. Though it was claimed that it copied ancient Chinese porcelain, such was not 
the case. Thomas Minton was among the designers of the Spode factory, and he went on to establish his own business which thrived largely on the production of the willow pattern, which became the "most widely produced image in the history of British pottery manufacture" $"$. It was catching, it told a story, the demand was insatiable. Even Josiah Wedgwood and his son John, when launching their own blue-printed earthenware and China vases, copied it: "Royal Worcester, Spode, Adams, Wedgwood, Davenport, Clews, Leeds and Swansea all produced versions of the printed design (Spode alone had three versions which were made from 1789 onwards [)]". Production was cheapened by the invention of transfer earthenware, and as the pattern was simply transferred onto the china, it became a common commodity.

The tale itself was invented after the pattern was produced, to further beautify the production of commodities (Mayo 454), and the tale proved as catching as the motif. Books were written about the so-called ancient Chinese legend, including tales for children and plays, whether melodramatic or parodic, like The Mandarin's Daughter. Dickens was amazed to see the willow pattern sitting among instances of Chinese porcelain and pottery in the 1851 Great Exhibition, and for Household Words he personified the "tirelessly self-promoting willow pattern dinner plate" (Chang 89-90). But there it was - reinvented British Chinese china was every bit as good as an original ( Elizabeth Chang comments on the "snowballing power of its cultural presence" as part of imperial practices; Chang 89$)^{8}$. A visual trope which sought to appropriate the Orient, the willow pattern created a homely, familiar image, as well as a visual trope fragmenting and distorting the Other. For Portanova, "Chinoiserie was not concerned with the real China, but a fantasy image of it." (Portanova 4)

And it is precisely because the story is a fake that Meredith's novel is so interesting. In Meredith's world, upper-class England has become a flawed copy of itself. Meredith is not simply seeking to debunk aestheticism and upper class refinement, in the manner of the caricature in Punch mocking Wilde (the engraving entitled "The Six-Mark Teapot" represents a newlywed couple hoping to live up to their teapot). No, he is actually presenting the English gentleman as a simulacrum, as if foreshadowing Baudrillard's anxious view of vanishing reality: “Ainsi partout l'hyperréalisme de la simulation se traduit par l'hallucinante ressemblance du réel à lui-même. Le pouvoir lui aussi ne produit plus depuis longtemps que les signes de sa ressemblance" (Baudrillard 41). If Clara is like "one of those delicate flowers, the ladies of the Court of China, on rice paper" (36), Willoughby is like the willow pattern, an English imitation of itself, preying on its empire and imperial cultural domination, stealing and subverting. The opening of the novel is steeped in Darwinian discourse, as Willoughby wants to cut the lower branches of the family (and ignore his poor relatives) and wishes to marry a good specimen of a woman, Clara. But the narrative voice subverts his smugness by introducing impish monkeys sitting in the "Oriental posture" (4), and reminding us that Willoughby and civilization are only one step away from beasts, and that his egoism is pure regression, regardless of social standing.

Besides, it is significant that Willoughby should begin his narrative career by travelling round the world, visiting "America, Japan, China", writing letters home, "holding an English review of his Maker's grotesques" (23). His wit becomes "placable flicks of the lionly tail addressed to Britannia the Ruler". The ironic narrative voice calls for a shift of power, away from the man in the mansion, back to the man of letters, though the surface symmetry is to be read backward, a perfect instance of Meredith's ironic 
ventriloquism: "But one was a Patterne; the other a Whitford. One had genius; the other pottered after him with the title of student. One was an English gentleman wherever he went; the other was a new kind of thing, nondescript, produced in England of late, and not likely to come to much good himself, or do much good to the country." (23). Willoughby Patterne's failure must be connected, metonymically, with Britain's failure to understand the world she claims to rule. The ersatz Chinese romance is a screen masking commercial imperialism. In Willow! David Richard Quinter considers the willow pattern as a product of the Empire, which the British took with them when they settled into new lands, whether Canada or Australia, South Africa or New Zealand, a product which also seduced America. Willoughby Patterne embodies the smugness of a nation which believes in its superiority, yet which has lost touch with ideas, creativity and the truth, mistaking cheap reconstruction for the legacy of art and other cultures. It is a myth, in Roland Barthes's sense of the word, an instantly recognizable generality, but also something frozen by its apparently irrelevant white lie: "This is because myth is speech stolen and restored." (Barthes 125)

To conclude, Meredith's Egoist runs against the grain of Victorian England and deserves to be re-examined, as it offers a feminine and even, implicitly, post-colonial perspective, yet drowns in its own witty, ventriloquist obscurity and length. Interestingly enough, the willow pattern still remains today an icon of British identity; in 1942, a cover of the New Yorker used the willow pattern, but replaced the birds with planes, a tribute to the British and their adamant resilience during the Blitz. The legacy is also problematized by the recurrence of the motif in areas connected with the former British Empire. Jane Urquhart, for instance, a writer who is particularly sensitive to the cultural links between Canada and Europe, uses the willow pattern as a key motif in her novel The Underpainter, where it hovers between absence and presence. For Australian artist Danie Mellor, the willow pattern is the key to orientalism: "This is the design that I identify as the beginning of the mis-telling of the orient". His paintings offer their own humorous revisions, as in his 2008 painting Dreaming beyond paradise (let sleeping giants lie), where a kangaroo lies asleep across the little bridge which recalls the willow pattern, while the scene is shaped like an oval dish: the painting discards the colonial narrative (the kangaroo represents the voicelessness of the Aboriginal people, as well as the Darwinian ideology used to vindicate colonialism). Thus the willow pattern remains a seductive, familiar yet shape-shifting motif, which may be used to problematize social and gendered hierarchy, as well as cross-cultural influences and colonial responsibility.

\section{BIBLIOGRAPHY}

Ackroyd, Peter. Chatterton. London: Hamish Hamilton, 1987.

Barthes, Roland. Mythologies. Trans. Jonathan Cape. New York: Hill and Wang, 1972.

Baudrillard, Jean. Simulacres et simulation. Paris: Galilée, 1981. 
Bloom, Harold. The Anxiety of Influence. 1973. New York, Oxford: Oxford University Press, 1997. Chang, Elizabeth Hope . Britain's Chinese Eye: Literature, Empire and aesthetics in Nineteenth-Century Britain. Palo Alto: Stanford University Press, 2010.

Cottereau, Serge. George Meredith: Les derniers romans (1880-1895). Paris: CNRS, 1986.

Dickens, Charles. “Old Lamps for New Ones.” Household Words 12 (15 Jun. 1850), 12-14.

http://www.engl.duq.edu/servus/PR_Critic/HW15jun50.html, 20 November 2012.

Donne, John. The Complete English Poems. Ed. A.J. Smith. Harmondsworth: Penguin Classics, 1996.

Forster, E.M. Aspects of the Novel [1927]. London: Penguin, 2005.

Garnett, Henrietta. Wives and Stunners: The Pre-Raphaelites and their Muses. London: Pan Macmillan, 2012.

Keats, John. Selected Poems. Ed. John Barnard. London: Penguin Classics, 2007.

Lang, Andrew. "Ballade of Blue China" in Ballads in Blue China, 1880.

http://www.online-literature.com/andrew_lang/ballads-in-blue/

October 12, 2012.

Mayo, Robert D. “The Egoist and the Willow Pattern”. In George Meredith, The Egoist. Ed. Robert M. Adams. New York: Norton, 1977, 453-460.

Mellor, Danie. "The Great Works of China: Blue and White Transferware- a soft colonisation of culture", keynote presentation to the 2009 Australian Ceramics Triennale.

http://www.craftaustralia.org.au/library/presentation.php?id=the_great_work_of_china

October 12, 2012.

Meredith, George. The Egoist. Ed. Robert M. Adams. New York: Norton, 1977.

---. The Ordeal of Richard Feverel. London: Chapman \& Hall, 1859.

---. Diana of the Crossways 1885 Detroit: 1897. Detroit: Wayne State University Press, 2001.

O'Hara, Patricia. “'The Willow Pattern That We Knew': The Victorian Literature of Blue Willow”. Victorian Studies 36 (Summer 1993), 421-442.

Portanova, Joseph J. "Porcelain, The Willow Pattern, and Chinoiserie by Joseph J. Portanova", http://www.nyu.edu/projects/mediamosaic/madeinchina/pdf/Portanova.pdf

October 12, 2012.

Quintner, David Richard. Willow! Solving the Mystery of Our 200-Year Love Affair With the Willow Pattern. General Store Publishing House, 1997.

Urquhart, Jane. The Underpainter. Toronto: McClelland \& Stewart, 1997.

Woolf, Virginia. “The Novels of George Meredith”, in George Meredith, The Egoist. Ed. Robert M. Adams. New York: Norton, 1977, 531-539.

\section{NOTES}

1. Andrew Lang, "Ballade of Blue China" in Ballads in Blue China, 1880. http:// www.online-literature.com/andrew_lang/ballads-in-blue/ October 12, 2012. 
2. A mandarin's daughter fell in love with her father's secretary; the angry mandarin ordered her to marry a wealthy suitor on the day when the blossoms fell from the tree (which may be seen on the right hand side of the motif); the lovers escaped over the bridge by the willow tree, then to an island, but their pursuers caught up with them and set fire to the house, whereupon the lovers turned into the birds which may be seen at the top of the motif (Mayo 455). Lang's poem pays tribute to the visual code which gives spontaneous access to ancient Chinese lore, said to derive from the mythical times of the yellow Emperor, Emperor Huang, some two thousand years BC.

3. For Bloom, all writing rewrites a previous piece of work, and reacts against it at the same time, misinterpreting and twisting the hypotext. Bloom defines the stages of the intertextual relationship, leading a writer to borrow from, then utterly reject his predecessors. He defines the following stages, clinamen (poetic misreading or misprision), tessera (completion and antithesis), kenosis (rejecting the predecessor as a kind of defence mechanism), akesis (claiming that one's work is unique, denying all influence), apophrades (opening up to the words of the predecessor and acknowledging his importance). Borrowing is often unconscious, therefore Bloom uses the image of "tessera", the significant fragment of pottery, to designate the fragments that recall the hypotext, under the guise of quotations, motifs or even plots: "A poet antithetically 'completes' his precursor, by so reading the parent poem as to retain its terms but to mean them in another sense, as though the precursor had failed to go far enough" (14). The fragment is a password, endowed with the trace of a lost aura: "The tessera was employed in early mystery religions where fitting together again the two halves of a broken piece of pottery was used as a means of recognition to the initiates." (Anthony Wilden, in Harold Bloom, The Anxiety of Influence, 67)

4. Whistler's title uses a Dutch expression referring to "long women", a porcelain figure here embodied by the reclining lady.

5. In William Henry Hunt's 1842 Hearing Lessons, willow pattern plates appear in the background in a plain cottage, a far cry from Whistler's and Rossetti's beautified interiors. William Henry Hunt was mostly known as a watercolor painter (a realistic painter of intimate scenes, as opposed to his namesake, Holman Hunt). Elizabeth Garnett recalls that the only letter extant from Lizzie Siddal to Gorgiana Burne-Jones mentions the willow pattern, visibly ascribing to the pattern a sentimental value ("With a willow-pattern dish full of love to you", Siddal in Garnett, 199); Garnett suggests that Rossetti's passion for the Dutch and Nankin blue-and-white china he collected, like Whistler, and which they referred to as Long Elizas (a pun on the Dutch name) may have come from his friend Ford Madox Brown, who "also appreciated the beauty of Dutch tiles and china but, being poor as a churchmouse in those days, he was reduced to buying the much cheaper, very pretty willow pattern plates then in common use" (Garnett 199). Willow pattern plates were part of daily life, not collected as aesthetic ornaments of value. Dickens, however, associates the Pre-Raphaelites and the willow pattern in his satiric pastiche of the Brotherhood: "In the first place, the Pre-Perspective Brotherhood will be presently incorporated, for the subversion of all known rules and principles of perspective. It is intended to swear every P. P. B. to a solemn renunciation of the art of perspective on a soup-plate of the willow pattern". Charles Dickens, “Old Lamps for New Ones”, Household Words 12 (15 Jun. 1850), 12-14. http://www.engl.duq.edu/servus/PR_Critic/HW15jun50.html, 20 November 2012.

6. Cottereau offers a subtle study of Meredith's use of the dramatic monologue, and the way in which the narrative voice mingles with internal focalization to mock a character to whose thoughts we seem to have direct access: "[La phrase] déguise une analyse, car nous savons bien 
que le héros n'a pu se tenir à lui-même, dans ces termes exprès, les propos qu'on lui prête, et que même s'ils traduisent le fonds secret de sa pensée, la vérité de ses sentiments, c'est l'auteur qui a opéré cette reductio ad essentiam (ou ad absurdum). Ce procédé, qui dans ses effets les plus cocasses, s'apparente au ventriloquisme, est essentiellement ironique, et d'une ironie indulgente ou féroce selon la nature de ce qu'il trahit." (Cottereau 328)

7. Danie Mellor, "The Great Works of China: Blue and White Transferware - a soft colonisation of culture", keynote presentation to the 2009 Australian Ceramics Triennale, http://www.craftaustralia.org.au/library/presentation.php?id=the_great_work_of_china October 12, 2012.

8. A film was made about the willow pattern legend in 1914, and the willow pattern's popularity has endured. Indeed, it is still manufactured today.

\section{ABSTRACTS}

An iconic emblem of the Victorian fascination for domestic objects with an exotic tang, the "willow pattern" reveals the problematic nature of the circulation of imperial commodities. A classic white and blue motif which was supposed to transpose an ancestral Chinese legend, the willow pattern was invented to cater to British taste. George Meredith's novel The Egoist refers to this imposture to engage with cultural capital and the relics of an aging world order. Playfully naming his protagonist Sir Willoughby Patterne, Meredith dissects social prejudices and emotional coldness, calling for a different culture.

Icône de l'Angleterre victorienne, le motif du saule offre un cas particulier d'imposture (née de la fascination victorienne pour l'objet familier empreint d'exotisme) qui problématise les modalités de circulation des biens dans l'Empire britannique. Exemple classique de motif de porcelaine bleue et blanche d'inspiration chinoise, le motif du saule est censé transcrire une légende ancestrale. Jouant par transparence sur le motif dans son roman The Egoist, George Meredith dénonce une société archaïque et la manipulation du capital culturel; Meredith dissèque la froideur émotionnelle de son protagoniste, jouant sur l'onomastique (Sir Willoughby Patterne) pour faire voler en éclats les conventions mortifères et appeler l'avènement d'une culture nouvelle.

\section{INDEX}

Keywords: china, desire, icon, imitation, imposture, myth, porcelain, prejudice, syllepsis, tessera, Willow Pattern

Mots-clés: désir, porcelaine, icone, imitation, imposture, mythe, parti-pris, syllepse, motif du saule 
AUTHORS

\section{CATHERINE LANONE}

Professeur

Université de Paris 3- Sorbonne

catherine.lanone@univ-tlse2.fr 